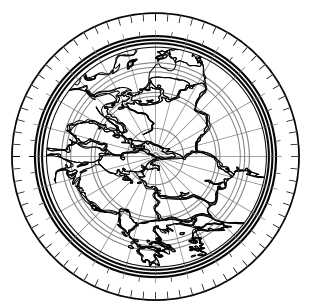

Sprawy Narodowościowe: Seria nowa, 2021(53), Article 2568

\title{
The "Othering" of the LGBT Movement as an Element of Populist Radical Right Party Discourse in Poland
}

DOI: https://doi.org/10.11649/sn.2568

\author{
Olena Yermakova \\ Jagiellonian University, Kraków \\ https://orcid.org/0000-0002-7208-0076 \\ e-mail: olena.yermakova@uj.edu.pl
}

\begin{abstract}
The article explores how the LGBT movement is "othered" to fit into right-wing populist discourse and is thereby utilised as an element of a political strategy by right-wing populist actors. I focus on Law and Justice (Prawo i Sprawiedliwość), a Polish populist radical right party (continuously in power since 2015), whose anti-LGBT rhetoric increased anew ahead of the 2019 European Parliament election. This study presents the results of a critical discourse analysis (conducted using Ruth Wodak and Martin Reisigl's analytical framework) of selected texts and visuals from the party's official website and from Twitter accounts of its prominent members. I analysed how the party representatives "other" LGBT Poles using discursive means, and how they frame homophobia within their broader populist discourse and instrumentalise it for political gains. I compare my findings to the findings from an analysis of Law and Justice's anti-migration discourse ahead of the 2015 parliamentary election. The study is conducted within the framework
\end{abstract}

This research is part of a project that has received funding from the European Union's Horizon 2020 research and innovation programme under grant agreement No. 765224.

No competing interests have been declared.

Publisher: Institute of Slavic Studies, Polish Academy of Sciences.

This is an Open Access article distributed under the terms of the Creative Commons Attribution 3.0 PL License (creativecommons.org/licenses/by/3.0/pl/), which permits redistribution, commercial and non-commercial, provided that the article is properly cited. (c) The Author 2021. 
of a larger study on "othering" as part of contemporary right-wing populism in Central and Eastern Europe.

Keywords: LGBT; homophobia; right wing; populism; Poland; Law and Justice party; discourse

\section{Introduction: The Context of the Situation of LGBT People in Poland ${ }^{1}$}

LGBT (abbreviation for Lesbian, Gay, Bisexual, and Transgender) is an umbrella term most often used to refer to the community of non-heterosexuals as a whole (UCSF LGBT Resource Center, n.d.). Other frequent abbreviations include LGBTA, LGBTI, LGBTQI, which articulate and add more specific identities and non-normative sexualities to the term (asexual, intergender, queer, respectively), and LGBT+, where the plus sign acknowledges all non-heteronormative identities without explicitly naming them. Another broad umbrella term is "queer". Originally pejorative, it has now been reclaimed by many persons of the community (ILGA-Europe, 2015). For the purposes of this paper, I use the abbreviation LGBT, as this is how the Law and Justice party (Prawo i Sprawiedliwość, hence the acronym PiS), which is in focus of this study, refers to it. More extensive abbreviations are not used in the party's discourse. Moreover, what is usually referred to is not LGBT persons per se but the movement for LGBT rights as a whole: a social movement "whose goal is to initiate and maintain socio-cultural, political and economic changes", which include a move away from the heteronormative model and the abolition of all forms of discrimination against non-heteronormative people (Bielska, 2021, pp. 14-15). It appears that PiS sees the LGBT solely as a movement, constantly using collective pronouns and nouns, rather than individuals with innate characteristics. This de-individualisation will be further explored in the analytical section of the paper.

As a conservative society characterised by a firm grip of the Roman Catholic Church, Poland has never been very accepting of the LGBT community. A comprehensive study by Campaign Against Homophobia (Kampania Przeciw Homofobii, KPH) has pointed out many challenges faced by non-heteronormative persons living in Poland, the situation being significantly worse for those residing in rural areas and small cities. These individuals often suffer from minority stress, depression, loneliness and suicidal thoughts, all the while being less likely to ask for help and mobilise. Other significant issues include not being accepted by family members (and the poor health associated with it), widespread homophobic and transphobic peer violence at schools, experienced violence, insufficient support and disregard for the problems of the LGBT community by government institutions, low reportability of homophobic and transphobic hate crimes, and the absence of legal regulations on samesex relationships. The study also points out the intersectional discrimination based on sexual orientation and poverty (Kampania Przeciw Homofobii, 2017).

1 A draft of the paper has been presented, among others, at Fatigue-Poprebel Seminar "Populism in Poland", online, 2 February 2021: https://populism-europe.com/poprebel/seminars/populism-in-poland/ 
What is especially relevant in the context of this paper is frequent contact with homophobic hate speech, experienced by LGBT Poles. According to $\mathrm{KPH}, 50 \%$ of gay men and lesbians encounter it on a regular basis. Importantly, the frequency of contact with hate speech is significantly correlated with mental wellbeing; frequent contact contributes to depression, loneliness, low life satisfaction and, in some cases, higher intake of medication. The absence of legal regulations against homophobic hate speech in public spaces is detrimental to the health and wellbeing of non-heteronormative Poles (Kampania Przeciw Homofobii, 2017).

While opposition to sexual minority rights in Poland is still among the highest in the European Union (according to Eurobarometer on Discrimination 2019, 45\% of respondents disagree that gay, lesbian and bisexual people should have the same rights as heterosexual people; European Commission, 2019, p. 1), attitudes towards LGBT people improved following Poland's accession to the bloc. Support for gay marriage and civil partnerships had been rising until 2019, when the increasingly hostile political environment began to take its toll (Shotter, 2019). Public Opinion Research Centre (Centrum Badania Opinii Społecznej, CBOS) surveys had shown a slow increase in openness to gays and lesbians in Polish society until 2019, when this trend stopped (CBOS, 2019, p. 3).

Many argue that the situation of the LGBT movement has been deteriorating since 2015 , that is, since its critics and political opponents came to power and started dominating the Polish political scene (Bielska, 2021; Figlerowicz, 2019). Bielska further notes that "openly homophobic associations and foundations are advisors to the government and state administration [...], and the homophobic Roman Catholic Church has a close relationship with the government" (Bielska, 2021, p. 16). According to a CBOS poll, in 2014, before PiS came to power, $77 \%$ of the surveyed Poles would accept a homosexual as their neighbour (Gąsior, 2014). A recent poll from 2019 reports that less than a third of Poles agree that same-sex couples should have the right to marry $(29 \%)$ and publicly show their way of life (28\%), while only $9 \%$ would allow them to adopt children (CBOS, 2019).

Indeed, 2019 saw a deterioration of the situation of LGBT people in Poland. Many of the more conservative south-eastern regions and municipalities declared themselves to be "zones free from LGBT ideology", while the right-wing magazine Gazeta Polska distributed "LGBT-free zone" stickers (Shotter, 2019). Tensions reached their peak in July, when football hooligans and far-right groups chased, beat and threw bottles and other objects at participants of the first equality march (the Polish equivalent of pride parades) in Białystok, a conservative city in the northeast (Dehnel, 2019). Slava Melnyk from KPH sums this up a follows:

Bialystok and the things that happened around the march were a tipping point in the public discourse regarding LGBTI issues in Poland and this part of Europe. [...] Physical violence was very rare, at least in this decade in Poland. Previously there were instances of hate crime, but violence to the extent that there was hunting of people and an almost pogromlike atmosphere, this hasn't happened before. (Shotter, 2019) 
Importantly, these tensions followed the mobilisation of anti-LGBT sentiment by PiS in the spring, or else, ahead of the European Parliament election (Cienski, 2019). Therefore, many claim that this increased homophobia was fuelled by PiS. The party "[had] sought to rally its conservative base by presenting itself as a bulwark against LGBT groups, which it portray[ed] as a threat to Catholic family values" (Shotter, 2019), the values that historically have been central to Polish identity (Mach, 2007). Mole et al. (2021) note that homophobia - the "irrational fear or intolerance of homosexuality or homosexual persons" (Herek, 1986, p. 563) - can be promoted by groups and governments, and identify Poland as a case in point. Bielska calls PiS "openly homophobic" (Bielska, 2021, p. 16) and notes that the incumbent President, Andrzej Duda, began his term in office by blocking the Gender Recognition Act. This strategy of constructing or evoking enemy images to rally support in an upcoming election based on fear is already a repetitive pattern for PiS, which will be further discussed in the next section.

The aim of this paper is to investigate how PiS has created a very successful rightwing populist narrative by incorporating the LGBT community in it as "Others", and even as enemies. By critically studying the use of LGBT in PiS discourse, I make an attempt to answer the following research question: How and why does PiS discursively "Other" the LGBT people and movement?

\section{Background: The Context of Law and Justice's Success and Discourse}

Law and Justice is a national-conservative, Christian democratic and right-wing populist party, according to the Popu-List (Rooduijn et al., 2019), or a populist radical right party, according to the classification proposed by Mudde (2007). In the European Parliament, they are part of the European Conservatives and Reformists group.

$\mathrm{PiS}$ has been in power in Poland continuously since 2015, managing to win every major election in the past half a decade. In the 2015 parliamentary election, PiS won the majority of seats in both the Sejm and the Senate, ${ }^{2}$ and the PiS candidate won the presidential election the same year. In the 2018 local elections, PiS received the highest number of seats in regional assemblies. In the latest European election, PiS also came first; its result rose by $13.60 \%$ compared to the previous European election, which makes it the party's best result to date (European Parliament, n.d.). Spring 2019, just before the European election, was when PiS employed anti-LGBT rhetoric. In the 2019 parliamentary election, $\mathrm{PiS}$ beat its competitors in both the Sejm and the Senate again.

In the latest election, the 2020 Polish presidential run, the topic of LGBT gained particular salience. PiS built its entire campaign around it, framing the election as almost a civilisational choice "between white-and-red Poland and rainbow Poland" (Tilles, 2020).

2 The lower and upper chambers of the Polish parliament, respectively. 
Despite pro-LGBT protests erupting in many Polish cities in (counter)reaction, the PiSbacked candidate won again.

How did PiS achieve such impeccable success? Many scholars, such as Klaus (2017), Krzyżanowski (2018), and Łaciak and Segeš Frelak (2018), to name a few, agree that an essential factor behind PiS's success in 2015 was how it managed to use in its campaign the so-called European migration crisis, which had unfolded just before the election. PiS constructed refugees as a threat, presenting migration as "an issue of security - both national, and cultural, direct and symbolic" (Klaus, 2017, p. 523). At the same time, PiS presented itself as a messiah that could save Poland from this threat. ${ }^{3}$ Later, in the 2018 local elections, PiS also tried to reuse the narrative whereby the opposition imposed a threat of refugees and PiS offered protection from the alleged threat. Arguably, this is a strategy of gaining fear-induced support: to create a problem so that you can offer a solution. Or, more precisely, to construct an enemy in order to provoke irrational fear, and then promise safety and security in the event of your election to the office.

Many observers note parallels between the use of anti-migrant and anti-LGBT discourses, noting "the same methods and same messages" (Gera, 2019). Indeed, PiS seems to consistently single out a minority group currently salient in public discourse and use it in its electoral campaigns: "Last time [in 2015] refugees were the candidate for the government to frighten people. [...] Now the gays are the new enemy for the government" (Shotter, 2019). A number of scholars (Bielska, 2021; Mole et al., 2021) observe that LGBT people have been repeatedly scapegoated by populist political actors in Poland, particularly in the 2019 European Parliament and 2020 Polish presidential election campaigns.

\section{Theory: Right-Wing Populism and its Enemies}

Since the current political era is characterised by "a populist Zeitgeist" (Mudde, 2004), it is hardly surprising that the question "What is populism?" has been widely debated in academia. There is a large body of academic literature trying to define populism using a variety of approaches (Gidron \& Bonikowski, 2014; Hawkins, 2010; Moffitt, 2016; Mudde, 2004; Müller, 2016; Panizza, 2005; Rooduijn \& Pauwels, 2011; Rovira Kaltwasser, 2012). ${ }^{4}$

I choose the concept of populism as a point of departure for my study - regardless of the approach, the consensus among scholars seems to be that populism is closely related to political polarisation, the redrawing of boundaries between groups and dividing societies into "Us" and "Them" (Gidron \& Bonikowski, 2014). As I argue, this is the discursive construction of the social world that PiS has been deploying. I take the ideational approach

3 For an analysis of constructions in PiS migration discourse see Yermakova (2019).

4 For more specific conceptualisations of populism, see working papers of the project POPREBEL, available at https://populism-europe.com/poprebel/poprebel-working-papers/ 
to populism here as it provides a clearer definition of this phenomenon and suits better my research goals.

Considering the ideational approach, first Mudde in 2004 and later Mudde and Rovira Kaltwasser in 2017 defined populism as

a thin-centered ideology that considers society to be ultimately separated into two homogeneous and antagonistic camps, "the pure people" versus "the corrupt elite", and which argues that politics should be an expression of the volonté générale (general will) of the people. (Mudde \& Rovira Kaltwasser, 2017, p. 6)

In his earlier work, Mudde further explains populism as "a Manichean outlook, in which there are only friends and foes. Opponents are not just people with different priorities and values, they are evil! Consequently, compromise is impossible, as it 'corrupts' the purity" (Mudde, 2004, p. 544). Therefore, thin populist ideology tends to be Manichean and a particularly moralistic imagination of politics, in which a morally pure, fully united, however, according to Mudde, ultimately fictional people are set against allegedly morally inferior elites. Consequently, the two major rivals of populism are elitism and pluralism (Müller, 2016).

A thin ideology, that is, one that does not provide answers to all of the major socio-political questions (Freeden, 1996), can be thickened, that is, combined with other ideologies to be complete in policy perspective. Mudde and Rovira Kaltwasser explain that "populism seldom exists in pure form. Rather, it appears in combination with, and manages to survive thanks to, other concepts" (Mudde \& Rovira Kaltwasser, 2017, p. 7). The "thickening" of populist ideology is defined by Kubik $(2018$, p. 6 ) as "a process via which populist ideology acquires additional features".

Populism can be combined with a wide range of ideologies, from socialism to ethno-nationalism (Bonikowski, 2017). Combination with nativism and authoritarianism makes (radical) right-wing populism (Mudde, 2007, as cited in Kubik 2018, p. 6), which is the concept I work with in my study. While studying populism in Central and Eastern Europe (CEE) it is important to consider a wider range of thickening agents, for instance religion, as they may be different or more prominent in CEE than in Western Europe (Allen, 2017). I argue that in the Polish case "othering" is a frequent thickening factor, which I explore by illustrating how it fits into the right-wing populist construction of the social reality.

A major work on right-wing populism in Poland is Rafat Pankowski's The Populist Radical Right in Poland: The Patriots - the first study of this kind available in English. Pankowski, too, adopts the ideational approach to populism, considering ideologies as "mental frameworks" through which actors interpret political reality. He adopts Mudde's definition of populism, but stresses the significance of cultural resources in a given society, "the traditions that legitimize particular aspects of political actions" (Pankowski, 2010, p. 6). He argues that populists' success is dependent on whether they manage to make this connection with culture. In the case of Poland, such "common sense" or "truths" derivative from culture 
include the claim that "all Poles are Catholics". With this he brings to the discussion of ideational approach to populism the role of traditional conceptions of the nation as a source of populist mobilisation (Gidron \& Bonikowski, 2014; Pankowski, 2010). Also other scholars (Buzalka, 2005; Wysocka, 2008) have pointed out the connection between populism and religion in the Polish case, with Buzalka even calling the Polish case "religious populism", and Kubik noting Roman Catholicism as an important thickening factor of right-wing populism in Poland.

To analyse right-wing populism it is not enough to look at the horizontal populist binary, "the people" vs "the elite"; rather, it is necessary to approach it in terms of a triad: "the people" vs "the elite" vs "the enemy". This allows to consider populist construction of the social reality as a two-dimensional space (Brubaker, 2017), where on the horizontal axis the 'good' people are juxtaposed to and threatened by "enemies" (usually "aliens"), and on the vertical axis they are separated from or ignored by 'bad' elites. Moreover, the elites often ignore or even exacerbate the danger that "aliens" pose, the "aliens" usually being immigrants (external "Others") or minorities (internal "Others"). They could also be very abstract, like an 'ideology' in the case under scrutiny. Thus, "the pure people" have enemies both "above" and "outside". This is constructed through discursive manoeuvres which set up symbolic boundaries between the imagined groups and define their cultural substances (by identifying their putative attributes). Besides, thick forms of populism tend to be characterised by missionary, moralistic passion (Kubik, 2018). As we see, enemy-making is an inherent part of right-wing populism. In my paper, I attempt to identify the instances of this threefold logic ("pure people" vs "corrupt elites" vs "aliens/enemies") in the populist ideology of PiS by critically analysing their discourse.

An intensifying production of enemy images has been analysed as one of the characteristics of recent CEE politics (Feischmidt, 2017). Gerő et al. (2017) write that there has been a rise of politics based on antagonism. They argue that apart from the analytical lens of populism and right-wing ideologies, it is essential to focus on the "images of the enemy" (Gerö et al., 2017, p. 17) that political actors construct, as well as the contexts in which they are used. Fergusson et al. (2014) argue that politicians need to construct or use enemies in order to gain electoral advantages, and that enemification is an action-legitimising strategy.

Enemy images are constructed by discursively "othering" a certain group first. Rephrasing Ramet, the "Other", who lies at the heart of radical right politics, is translated into "the Enemy" (Ramet, 1999, p. 4). "Other" and the notion deriving from it, "otherness", which was originally coined within post-colonial theory, is an interdisciplinary concept par excellence. The idea of "othering" originates from the presence of a minority politically labelled as "Others" in a society. Constructivist theories stress that identities involve a relationship with the "Other" as they are often defined in contrast to who the "Other" is (e.g. Hopf, 2002; Neumann, 1999). The "Other" is a concept constructed by the "Self", and both concepts can change, extend, adapt through time and historical contexts 
(Erkem, 2009; Hall, 2001). Dervin summarises this the following way: "Othering means turning the 'other' into an other, thus creating a boundary between different and similar, insiders and outsiders" (Dervin, 2015, p. 2).

Importantly, emotional and cognitive mechanisms that lead to "othering" are articulated linguistically and constructed interactively at different levels, which necessitates analysing discourse to study the processes of "othering". For Chebel d'Appollonia (2011, p. 11 in Dervin, 2015) "othering" corresponds to the "taxidermy of identity", which means confining the "Other" to a solid form, a restricted understanding of who he or she is and what they represent. In sociology, "othering" usually refers to differentiating discourses that imply moral and political judgments of superiority and inferiority between the so-called "Us" and "Them". "Othering" can base upon many and varied identity markers: nationality, race, gender, language, religion, etc. A common way of describing the "Other" is through a deficit framework: "they" are not as good or capable as "we" are, which leads to stereotypes of and prejudice against certain groups, their perceptions as inferior, and further - to their dehumanisation and demonisation. In this understanding, power is always employed in the different representations of "Other" and "Self". The phenomena described above take place through the construction and (re)negotiation of representation between "Self", "Other", and contexts. It is important to note, however, what Diez (2005) points out: not all "othering" practices are related to discrimination or exclusion, sometimes merely to differentiation without an implied threat or a derogatory intention.

Enemies, or threatening "Others", can take various forms: they can be a person, a minority group, another state, organisation or even something abstract. Scholars propose various typologies of enemies, such as personal and public (Holt \& Silverstein, 1989), individual and national (Jung et al., 2002), or limited, real and absolute (Schmitt, 2007). Mudde (2007) offers a very extensive typology of "enemies" of right-wing populists, noting three special cases: Muslims, Jews and Roma, who are most frequently "othered" and blamed. Gerő et al. (2017), who argue that enemy discourse has become more aggressive and explicit in Europe recently, note particular hostility to vulnerable social groups, such as the poor, national minorities, immigrants and LGBT people. Another group that they see "enemised" is political adversaries (opposition parties, NGOs, trade unions), as there are calls to restrict them in their activities (which are preconditions for authoritarianism, one of the main thickening factors of right-wing populism).

When it comes to LGBT groups, they are a recent enemy in public discourse, where they appear in this function as a counter-reaction to queer activism or more broadly, to liberal values promoted by the EU. In Poland, they are presented as "enemy of the family" (Mizielińska \& Stasińska, 2013). In my further analysis, I deconstruct the right-wing populist discursive triad ("the pure people" vs "the corrupt elite" vs "aliens/enemies") in the case of PiS discourse employed in 2019, and explore how LGBT community is "othered" as an enemy within the right-wing populist triad. 


\section{Methodological Note: Analysing Discourse}

This study relies on the methodology of Critical Discourse Analysis (CDA), as it aims at critically examining the use of language to explore social issues (Regmi, 2017). In particular, I apply the analytical framework of CDA proposed by Ruth Wodak and Martin Reisigl (2001), ${ }^{5}$ as it was developed specifically for research purposes similar to those pursued here: investigating how discrimination is reflected in and shaped by discourse. This methodological framework is centred around identifying discursive practices which position people in societal structure, which in turn (re)produces unequal power relations in a society.

For the sake of consistency, I use the definition of discourse as adapted to CDA by the major approach to the study of discourse that I follow - the discourse-historical approach. The proponents of the approach see discourse, that is, language use in speech and writing, as a form of "social practice" (after Fairclough \& Wodak, 1997), and consider the "context of language use" to be crucial. Such an approach implies "a dialectical relationship between a particular discursive event and the situation(s), institution(s) and social structure(s), which frame it: The discursive event is shaped by them, but it also shapes them". This means that discourse is

socially constitutive as well as socially conditioned - it constitutes situations, objects of knowledge, and the social identities of and relationships between people and groups of people. It is constitutive both in the sense that it helps to sustain and reproduce the social status quo, and in the sense that it contributes to transforming it. Since discourse is so socially consequential, it gives rise to important issues of power. Discursive practices may have major ideological effects - that is, they can help produce and reproduce unequal power relations between (for instance) [...] ethnic/cultural majorities and minorities through the ways in which they represent things and position people. (Fairclough \& Wodak, 1997, p. 258)

Hence, within this methodology discourses are understood as "relatively stable uses of language serving the organization and structuring of social life" (Wodak \& Meyer, 2008, p. 6). As Wodak and Reisigl (2015, pp. 583-585) further elaborate, discursive practices are socially constitutive, among other reasons, because they enable the construction of collective subjects (such as 'races'), justifying a certain social status quo and producing certain (unequal) social conditions.

Reisigl and Wodak have analysed discursive components of discrimination and organised them into five discursive strategies, which, as they find, "are all employed for the positive self- and negative other-presentation" (Wodak \& Reisigl, 2015, p. 585). These are: (1) nomination; (2) predication; (3) argumentation; (4) perspectivation, framing, or discourse representation; (5) intensifying or mitigation. Due to the limited space and clearly articulated scope of this paper, the discussion is confined to three most salient strategies: nomination, predication and argumentation.

5 The framework was laid out in chapter "Discourse and Racism" in The Handbook of Discourse Analysis in 2001 but I mostly use later works by the authors, particularly the recent second edition of the book (Wodak \& Reisigl, 2015). 
Nomination strategies construct and represent social actors (e.g. ingroups and outgroups) via membership categorisation devices (including making reference by tropes, such as naturalising and depersonalising metaphors, metonymy, synecdoche). Hence, when looking at nomination strategies we examine how social actors are named and referred to linguistically.

Predication strategies depict social actors, and "may be realized as stereotypical attributions of negative and positive traits in the linguistic form of implicit or explicit predicates" (Wodak \& Reisigl, 2015, p. 585). When looking at predication strategies, then, we investigate which characteristics and features are attributed to the social actors in focus.

Argumentation strategies are processes employed to justify claims of truth and normative validity. They often rely on topoi, i.e. argument schemes, which are used to link the premise of an argument to its conclusion (Kader, 2016, p. 29). They are the tools via which "positive and negative characteristics are legitimized and racist discrimination against racialized Others is justified, usually by employing various fallacies" (Wodak \& Reisigl, 2015, p. 585).

I see the end goal of these strategies in justifying, or legitimising, the unequal power relations between the majority, in this case heterosexuals, and the minority, in this case the LGBT people. Hence, in my study I aim to uncover the nomination, predication and argumentation strategies that PiS used to discursively construct LGBT Poles as "Others" and thereby justify their discrimination.

In addition, the analysis also looks into parallels with PiS migration discourse. Thereby I investigate elements of intertextuality and interdiscursivity, which are essential to the discourse-historical approach as part of its historical facet (Wodak \& Reisigl, 2001, p. 90). Variety of empirical data supplemented with wide background information is one of the distinguishing features of the approach, as it heavily relies on context (Wodak \& Reisigl, 2015, p. 583). ${ }^{6}$

$I$ analysed the news, interviews and other publications from the official website of the PiS party (pis.org.pl). The research sample was selected using the following search keywords: 'Igbt' (4 articles matching, all from 2019); 'homosexual' ( 3 articles matching, all from 2019); 'lesbian' (1 article matching, 2019); 'family values' (1 article, 2019); 'Christian values' (1 article, 2017); gay ( 1 article, 2019); 'same sex marriage' (no matches). Some of the identified articles overlap, yet all of them were analysed.

Additionally, in order to explore intertextuality and different genres, I analysed tweets from the official Twitter account of PiS (@pisorgpl), and eleven of its prominent members active on Twitter: Andrzej Duda (@AndrzejDuda), Mateusz Morawiecki ${ }^{8}$ (@MorawieckiM), Beata Szydło9 (@BeataSzydlo), Mariusz Błaszczak ${ }^{10}$ (@mblaszczak), Elżbieta Rafalska ${ }^{11}$

\footnotetext{
6 This is discussed in more detail in Reisigl \& Wodak, 2001, p. 41.

7 President of Poland, first elected in 2015 as PiS candidate.

8 Prime Minister of Poland since 2017.

9 Prime Minister of Poland between 2015 and 2017. Since 2019, Member of the European Parliament, ViceChair of the European Conservatives and Reformists.

10 Minister of National Defence since 2018.

11 Minister of Family, Labour and Social Policy between 2015 and 2019. Since 2019, Member of the European Parliament.
} 
(@E_Rafalska), Jacek Sasin ${ }^{12}$ (@SasinJacek), Jadwiga Wiśniewska ${ }^{13}$ (@j_wisniewska), Marek Kuchciński ${ }^{14}$ (@MarekKuchcinski), Piotr Gliński ${ }^{15}$ (@PiotrGlinski), Stanisław Karczewski ${ }^{16}$ (@StKarczewski), Paweł Lisiecki ${ }^{17}$ (@lisieckipawel), as well as The Chancellery of the Prime Minister (Kancelaria Premiera) (@PremierRP) and the Ministry of Family, Labour and Social Policy (Ministerstwo Rodziny) (@MRPiPS_GOV_PL).

Twitter accounts of PiS members are an interesting source as their discourse is less mitigated, compared to the official party website. The sample was selected by searching for the same keywords as above. The results were the following: 'Igbt' - 68 matches; 'homosexual' - 3 matches; 'lesbian' - 1 match; 'gay' - 2 matches; 'family values' - 227 matches; 'Christian values' - 216 matches. Many of those results overlap. Primary focus was put on the sample generated using the keywords 'Igbt', 'homosexual', 'gay' and 'lesbian', as per the objectives of the study: to explore how LGBT people are constructed in PiS discourse. The material generated using the keywords 'Christian values' and 'family values' provided supporting material. Results matching the keyword 'same sex marriage' were left out, as due to the fact that in Polish the phrase consists of five words (małżeństwa osób tej samej płci) there were many false matches (1,514 matches in total). The material was collected and coded using NVivo and Ncapture software.

Considering that all original data is in Polish, the search by keywords was conducted in Polish, accounting for all possible grammatical forms of the nouns. All translations from Polish into English are the author's own. The main limitation of searching by keywords is that it does not account for subtle references and euphemisms. This, however, does not seriously limit this study, as its aim is to investigate purposive discourse on LGBT community. The empirical research was conducted between November and December 2019.

\section{Analysis and Interpretations: How and Why Populists "Other" LGBT}

The first thing that became visible while analysing the data was the timing of the collected material. All but one of the articles analysed from PiS's website were dated within two months from an important election: 3 from May 2019, 2 from March 2019 (before the European elections of 2019), 2 from October 2019 (one of which right before the 2019 Polish parliamentary election), and one from November 2017. The same tendency to ignite debate around LGBT issues was also noticeable on Twitter, particularly in the spring of 2019. This allows me to suggest that indeed the issue was brought up instrumentally to mobilise conservative voters.

12 Deputy Prime Minister and Minister of State Assets since 2019.

13 Member of the European Parliament since 2014.

14 Member of the Sejm. Marshal of the Sejm between 2015 and 2019.

15 Deputy Prime Minister and Minister of Culture, National Heritage and Sport since 2015.

16 Marshal of the Senate between 2015 and 2019.

17 Member of the Sejm since 2015. 


\section{Observed Nomination Strategies}

I started my analysis by investigating how LGBT were named and referred to. I classified the identified names into two types: neutral or negative in their connotation. Some of the most frequent and interesting examples can be seen in Table 1. It has to be noted that the decision whether a given name is neutral or not was context-bound and could be different in other texts and contexts. Importantly, no positive nominations were identified.

Table 1: Examples of names used to refer to the LGBT people and movement taken from PiS website and the analysed Twitter accounts

\begin{tabular}{|c|c|}
\hline Neutral & Negative \\
\hline LGBT activists $^{18}$ & rainbow plague $^{19}$ \\
\hline LGBT community ${ }^{20}$ & leftist avalanche $e^{21}$ \\
\hline LGBT movements ${ }^{22}$ & the sick ideology $y^{23}$ \\
\hline homosexual couples ${ }^{24}$ & ideological revolution ${ }^{25}$ \\
\hline homosexual circles ${ }^{26}$ & cultural war $^{27}$ \\
\hline the LGBT case $^{28}$ & sexualisation of children ${ }^{29}$ \\
\hline
\end{tabular}

In the right column of Table 1, we can observe how dramatising and intensifying the language used is. It is also noticeable that when it comes to negative nominations, these are derogatory ideologonyms, such as "the sick ideology". They serve to describe the whole movement rather than constitute personalised offences against non-heterosexuals. The second observation is that in the sample there were very few search results matching 'gays', 'lesbians' or 'homosexuals'; most of the results were those matching 'Igbt'. Hence again, the nominations used were not necessarily personalised attacks against LGBT persons.

However, it was also mentioned in a tweet that "the purpose of the acronym LGBT is to falsify (hide) reality". ${ }^{30}$ It may be derived that both sides of the debate accuse each other of treating LGBT as a floating signifier. PiS accuses LGBT Poles of hiding some alternative

18 Paweł Lisiecki, retrieved from Twitter account @lisieckipawel.

19 An especially vivid term coined by the Archbishop of Kraków, repeated in Twitter discourse by PiS members. Retrieved from Jadwiga Wiśniewska's Twitter account @j_wisniewska.

20 Paweł Lisiecki, retrieved from Twitter account @lisieckipawel.

21 Paweł Lisiecki, retrieved from Twitter account @lisieckipawel.

22 Jacek Sasin, retrieved from Twitter account @SasinJacek.

23 By Zofia Klepacka, retweeted by Paweł Lisiecki.

24 Jarosław Kaczyński (Polska Plus czy Polska Minus, 2019).

25 Jacek Sasin, retrieved from Twitter account @SasinJacek.

26 Paweł Lisiecki, retrieved from Twitter account @lisieckipawel.

27 Jarosław Kaczyński (Polska Plus czy Polska Minus, 2019).

28 Mateusz Morawiecki (Wybory zdecyduja, 2019).

29 Beata Szydło (W Europie głosuj za Polską!, 2019).

30 Paweł Lisiecki, retrieved from Twitter account @lisieckipawel. 
meanings behind the term, hiding an ideological agenda, presumably. At the same time, the LGBT community accuses PiS of doing the same and using the concept for political gains by filling it with their own, often derogatory, meanings.

The strategy of dehumanising the LGBT movement was also at the centre of the presidential campaign a year later (2020). ${ }^{31}$ Fighting for re-election, PiS-backed candidate and former party member Andrzej Duda claimed at one of his rallies: "They are trying to convince us that this [LGBT] is people, but this is just an ideology" (Tok FM, 2020). This rhetoric caused a wave of protests across the country. One frequent element of those protests were signs reading "LGBT are people, not an ideology", which directly referenced Duda's words and expressed opposition to such discourse. His words were literally dehumanising: he rhetorically deprived LGBT Poles of their humanity. Being part of campaigning, this was arguably intentional. "My life is not your electoral slogan", a sign said (Yermakova, 2020), calling out the use of minorities in political campaigning. According to an analysis of a counterdemonstration during Duda's visit to Kraków, one possible explanation for this instrumental dehumanisation is as follows:

\begin{abstract}
Christian values, which PiS allegedly adheres to, imply loving thy neighbour and treating each human as a child of God. So to justify mistreatment, you need to first dehumanise the enemy, in this case by calling them an ideology. Or, like in the case of refugees, by calling them a flooding, and using a language to describe them, comparable to the one Nazis used in regard to Jews. This is an extremely dangerous path to take, especially towards your own citizens. (Yermakova, 2020)
\end{abstract}

Another aspect of fallacies in nomination is that much of the discourse on LGBT rights in Poland is purposefully confused with the notion of "gender politics and sexualisation of children". ${ }^{32}$ The latter phrase in particular adds a strongly negative connotation to the movement, especially in the light of numerous recent scandals concerning child molestation by members of the Polish Catholic clergy. As for gender, while anti-gender campaigns were started in Poland by the Polish Roman Catholic Church around 2012, some scholars note that PiS has picked them up and "made attacks on 'gender ideology' a key element of the critique of individualism and neoliberal globalisation" (Korolczuk, 2019, p. 165).

\title{
Predication Strategies
}

The objective of predication strategies is to discursively qualify social actors (more or less positively or negatively) by means such as: stereotypical, evaluative attributions of negative or positive traits (e.g. in the form of adjectives, appositions, prepositional phrases, relative clauses, conjunctional clauses, infinitive clauses and participial clauses or groups); explicit predicates or predicative nouns/adjectives/

31 For a discussion of the links and an analysis of the campaign, see Heilig \& Lenik (2020).

32 Beata Szydło (W Europie głosuj za Polską!, 2019). 
pronouns; collocations; explicit comparisons, similes, metaphors and other rhetorical figures (including metonymies, hyperboles, litotes, euphemisms); allusions, evocations and presuppositions/implicatures (Kader, 2016, p. 30). In short, in this section I attempt to identify and analyse how the "Others" are described and what qualities and features are attributed to them.

I summarise my analysis in the table below. In particular, I identify topoi in the description of LGBT persons or movement in PiS discourse (on the right). On the left, I present only a selection of quotes to illustrate linguistic realisations of "othering", while the topoi are derived from the entirety of the analysed data. Many of the topoi overlap. For instance, 'anti-Polish' below is illustrated with a quote that could also be labelled as 'anti-religious'. That is because the implication of the speaker is that Christian religion is an inherent part of 'our' (i.e. Polish) culture, which has been mentioned in the Theory section above. At the same time, utterances on different topics could all serve to (re)produce the same topos. For instance, whether describing the LGBT movement as an attack on Polish culture or on children, the implied meaning either way is that the LGBT movement is a threat.

Table 2: Examples of predication strategies

\begin{tabular}{|c|c|}
\hline Utterances & Topoi \\
\hline $\begin{array}{l}\text { a constant attack on everything that constitutes our cultural circle, } \\
\text { including, of course, the Christian religion }{ }^{33}\end{array}$ & $>$ Anti-Polish \\
\hline offending religious feelings ${ }^{34}$ & $>$ Anti-religious \\
\hline those who try to get to the children ${ }^{35}$ & $\begin{array}{l}>\text { Child molester } \\
>\text { Dangerous/threat }\end{array}$ \\
\hline $\begin{array}{l}\text { walks with abortionists, leftists and communists, will fight with them } \\
\text { against the Church and religion at schools, and bring refugees }{ }^{36}\end{array}$ & $\begin{array}{l}>\text { Leftist/communist } \\
>\text { Traitor }\end{array}$ \\
\hline 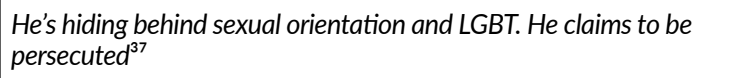 & $>$ Liar/manipulator \\
\hline LGBTs could speak up and tell everyone how to live in fewer areas $^{38}$ & $>$ Pretentious \\
\hline $\begin{array}{l}\text { They themselves stigmatise the LGBT circle [...] a diversity tram, and } \\
\text { the rest are to ride ordinary trams; [...] separate council hostels, and } \\
\text { the rest waiting for a council flat for two years }{ }^{39}\end{array}$ & $\begin{array}{l}\text { Demanding special treatment } \\
\text { Provocateur }\end{array}$ \\
\hline
\end{tabular}

33 Jarosław Kaczyński (Polska Plus czy Polska Minus, 2019).

34 Jadwiga Wiśniewska, retrieved from Twitter account @j_wisniewska.

35 Paweł Lisiecki, retrieved from Twitter account @lisieckipawel.

36 Paweł Lisiecki, retrieved from Twitter account @lisieckipawel.

37 Paweł Lisiecki, retrieved from Twitter account @lisieckipawel.

38 Paweł Lisiecki, retrieved from Twitter account @lisieckipawel.

39 Paweł Lisiecki, retrieved from Twitter account @lisieckipawel. 
Particularly the last quote above illustrates the suggestion that LGBT Poles demand special treatment, implying that they want to be different from the rest. Hence they are "Others" by their own making. PiS implicitly communicates: it is not us "othering" them or discriminating against them, they are the ones "othering" themselves, and if we provide what they ask for, it is 'normal' Poles that will be discriminated against.

PiS seems to deliberately and repeatedly single out a minority group to threaten the majority and to provoke inter-group conflict by constructing perceived inter-group competition. At the same time, they present themselves as those who defend the interest of the majority, which fits into the populist notion of advocating the volonté générale in politics.

The notion of a 'pure' homogenous people, central to populism as an ideology, is particularly applicable to and sensitive in Poland. Due to historical reasons, the collective identity of her people has been shaped by ethnicity and cultural tradition and values, particularly Catholic ones, rather than political common denominators (Porter, 2001). The notion of Polish nation is that of an ethnic rather than civic one. Since "othering" is tied to identity-building, if collective identity is defined by culture, the "Others" are also culturally constructed. Those are "othered" whose culture and identity differ from the common homogenous Polish ones. "Others" are seen as those who do not want to or cannot assimilate, thereby threatening the cultural homogeneity of Polish society, which is perceived as the basis of its nationhood, and causing fears. Mole explores how homophobia in Latvia (Mole, 2011), and recently in Poland (Mole et al., 2021), is explained by nationalism, and how homosexuality is framed as the "national threat". Polish identity is seen as inherited and imposed, not allowing for any deviation from the cultural 'norm', any 'other' way of thinking, even if it comes from within. Hence, homophobia is an example of inner "othering". This pattern of collective identity is common throughout the entire CEE region, and it is particularly strong in Poland due to extreme homogeneity since World War II. And since Polish society perceives itself as a community of common national culture and identity, claiming a different identity is seen as a threat to the nation. This may explain why one of the most frequent tropes in PiS discourse on LGBT issues is claiming that it is anti-Polish.

\section{Us vs Them}

A very common trope in populist discourse as a whole, and PiS discourse in particular, is the "Us vs Them" antagonism, where "Us" are primordially good and "Them" are primordially bad. It has been noted by many scholars in migration discourse with regard to refugees (Klaus, 2017; Yermakova, 2019).

Building upon the points mentioned above, I further explore the thematic contents of "othering". Thereby, I analyse how the difference between "Us" and "Them" is linguistically constructed. The selected quotes are as follows: 
LGBT want equal rights. Not true! They want privileges, because the possibility of adopting a child is a privilege [...] the child's right [is] to have a father and a mother. ${ }^{40}$

I have nothing against gays and lesbians but only against the privileges of belonging to LGBT. ${ }^{41}$

We laugh at Podlasie, Podkarpacie or Masurian villages, but l'll tell you that all this progressiveness, LGBT etc. will never arrive there. These will be the last bastions of normality if we don't stop this leftist avalanche. ${ }^{42}$

This is an attack on our identity. On Polish culture. ${ }^{43}$

These quotes illustrate the implied specialness of the LGBT community and their abnormality compared to the 'normal' Poles, a point mentioned above. Furthermore, LGBT Poles, according to PiS, threaten the unity and homogeneity of the Polish people as well as Polish culture and Polishness itself.

The implied differences between these imagined groups, 'normal' Poles ("Us") and LGBT people ("Them") seems to be the following. 'Normal' Polish people seem to be homogenous, Catholic, traditional, conservative, heterosexual and child-bearing, but above all underprivileged, humble and in need of protection. LGBT persons are presented as progressive and leftist (and therefore foreign and dangerous, not 'pure'), but also elitist due to perceived extra privileges. This might explain why the LGBT movement is such a problem in the populist worldview: it is seen not only as alien, the enemy "outside" (on the horizontal axis), but also, in a way, as "the corrupt elite", so the enemy "above" (on the vertical axis) at the same time. This might be exacerbated by the fact that LGBT activists are described as leftist, which in public perception is often conflated with being communist. And communists are perceived as the traditional "corrupt elite" in CEE countries (Kubik, 2018).

\section{Argumentation Strategies}

The last but perhaps the most important part of the analysis identifies argumentation strategies. Here, I analyse the argumentation schemes employed to legitimise the exclusion of "Others", in this case the LGBT people and movement.

Below is a table where on the left there are some selected utterances, and on the right - conclusions from the analysis. Here too, the table serves as merely an illustration, since the strategies were extracted from the entire body of data and supplemented with a broader context.

40 Paweł Lisiecki, retrieved from Twitter account @lisieckipawel.

41 By Zofia Klepacka, retweeted by Paweł Lisiecki.

42 By Zofia Klepacka, retweeted by Paweł Lisiecki.

43 Mateusz Morawiecki (Nowa Piątka PiS, 2019). 
Table 3: Examples of argumentation strategies

\begin{tabular}{|c|c|}
\hline Utterances & Argumentation strategies \\
\hline $\begin{array}{l}\text { NO to gender ideology and LGBT } \\
\text { ideological war }\end{array}$ & $>$ Protecting against foreign influence \\
\hline a threat to the $[\mathrm{EU}]$ member states ${ }^{46}$ & $\begin{array}{l}\text { Protecting national sovereignty/interests and Polish } \\
\text { values, "Polishness" }\end{array}$ \\
\hline $\begin{array}{l}\text { defending the rights of parents and children }{ }^{47} \\
\text { No to the attack on children. We won't be bullied. We will } \\
\text { defend Polish families }{ }^{48}\end{array}$ & $>$ Protecting the Polish family and children \\
\hline protect our values $^{49}$ & $>$ Protecting Catholic values and religious feelings \\
\hline $\begin{array}{l}\text { LGBT+ declarations will be incompatible not only with laws, } \\
\text { but with the Constitution in general }\end{array}$ & $>$ Abiding by the Constitution \\
\hline I demand separation of LGBT from the state ${ }^{51}$ & $\begin{array}{l}>\text { Need for authorities to focus on more important } \\
\text { problems } \\
>\text { Sexual orientation - private, not public matter, and } \\
\text { protecting privacy }\end{array}$ \\
\hline Parents have the right to decide ${ }^{52}$ & $>$ Arguing autonomy for "the people" \\
\hline
\end{tabular}

As already mentioned, it seems that the main line of argumentation is to present the LGBT movement as "a threat to the Polish nation and its shared norms and values, particularly those derived from religion" (Mole et al., 2021, p. 1). To construct a threat to the nation, there is an evident recontextualisation of discourse on struggling against communism in the twentieth century. Most notably, during the infamous presidential rally in Brzeg Andrzej Duda not only called LGBT an ideology but also claimed: "This was not what my parents' generation had fought for for forty years, in order to expel communist ideology from schools [...] that's not what they fought for, so that now we would agree to a different ideology, even more destructive for a human" (Tok FM, 2020). In the context of the recent history of communism, a foreign imposed ideology and regime, calling the movement for rights of LGBT persons a foreign import that threatens the Polish nation (Gera, 2019) is unsurprisingly an effective and fear-inducing strategy. It is also an emotional manipulation, which is quite characteristic of populist discourse.

Constructing a certain group of citizens as a threat to the nation, a public enemy or a fifth column, is of course problematic in a liberal democratic system. Not only do such

44 Jadwiga Wiśniewska, retrieved from Twitter account @j_wisniewska.

45 Beata Szydło, retrieved from Twitter account @BeataSzydlo.

46 Paweł Lisiecki, retrieved from Twitter account @lisieckipawel.

47 Beata Szydło, retrieved from Twitter account @BeataSzydlo.

48 Stanisław Karczewski, retrieved from Twitter account @StKarczewski.

49 Jadwiga Wiśniewska, retrieved from Twitter account @j_wisniewska.

50 Paweł Lisiecki, retrieved from Twitter account @lisieckipawel.

51 Paweł Lisiecki, retrieved from Twitter account @lisieckipawel.

52 Beata Szydło (W Europie głosuj za Polską!, 2019). 
discursive practices legitimise discrimination, legitimise certain citizens having less rights than others, but also potentially even lay the groundwork for denying them as citizens altogether, stripping them of any civil and political rights.

However, PiS is overall careful in its discourse. First of all, most of the especially emotion-laden or blatant utterances come from Twitter accounts of its members, not from the official party website. Most of the debate around the LGBT issue was conducted in social media or in oral communication, finding only little reflection on the website. Secondly, aware of the controversy, PiS tries to position its anti-LGBT discourse within positive, not negative structures: saying we are "not AGAINST gays and lesbians", but "we are FOR Polish families and Polish values".

\section{Parallels with Discourse on Migration}

To put this study in a broader perspective, and explore interdiscursivity, I compared my findings with those from the analysis of PiS migration discourse (Yermakova, 2019). Below I present the common features, tropes and topoi identified.

An overwhelming appeal to emotion, and little appeal to rationality

This is observed throughout both LGBT and migration discourses. Both issues have become moral panics ${ }^{53}$ (Cohen, 2011), and this was induced with the use of dramatising vocabulary, such as "rainbow plague" or "refugee flood", that constructs a dehumanised collective and also constructs a threat.

\section{"Us vs Them" antagonism}

As discussed above, this is a very common topos in both discourses. "Us" or "Self" stands for 'normal' Poles and is conflated with the PiS government, which claims to represent their will. By extension, the two are conflated with Poland on the level of both the society and the state. "Them" can take different forms: the specific enemies, immediate antagonists, are discoursespecific, either refugees (or migrants more broadly) or non-heterosexuals. However, in either case they are constructed as a foreign threat that is imposed or exacerbated by "the corrupt elite".

\section{Multiple levels of "the corrupt elites"}

As just mentioned, constructions of enemies are a multitude and they are embedded in each other. Depending on the specific discourse, the horizontal "enemies/aliens" are either the LGBT or refugees. However, at the same time they can be constructed as a "corrupt elite", as they are claimed to have privileges over 'normal' people (in the case of refugees, social benefits are usually seen as such). The perceived threat that these enemies pose

53 Based on Cohen's theory of moral panics, I understand moral panic as a widespread fear of a perceived threat to values, social norms and interests of a community, which is generated by politicians and news media, and which results in introducing new laws targeting the threat and in a social change within the community (Cohen, 2011). 
is constructed as being brought onto "the pure people" by "the corrupt elite" composed of Law and Justice's political opponents. The main protagonist here is PiS's greatest competitor: the Civic Platform party (Platforma Obywatelska, PO), either as a whole (during the 2018 local election campaign, in migration discourse) or personalised and targeted (in migration discourse, e.g. Donald Tusk, co-founder of PO and former President of the European Council; in LGBT discourse, e.g. Rafat Trzaskowski, PO's candidate in the 2020 presidential run). Furthermore, Polish political opponents of PiS are constructed as being subject to foreign influences and interests, particularly those of the EU/West. The ultimate "corrupt elite", then, in both discourses is the EU seen as, to quote PiS, "Brussels elites" (also the "old EU" or vaguely Western European countries). Like in the case of local "corrupt elites", sometimes the enemy is, metaphorically speaking, given a face. In migration discourse, German Chancellor Angela Merkel was constructed as the personalisation of the so-called refugee threat imposed by the EU. In the case of LGBT discourse, during the 2019 European election campaign, Frans Timmermans, then lead candidate for the President of the European Commission from the Party of European Socialists, was constructed as the embodiment of the perceived LGBT threat being imposed on Poland by Brussels.

\section{$E U$ is an ideological opponent and an usurper, an antagonist}

Building on the point above, an interesting finding is that in both cases the EU is constructed as the cause of the above-mentioned "threats", a foreign power trying to convert Poland to their foreign and mad ideology. This construction and "othering" of the EU in PiS discourse is worth exploring deeper as a separate issue. In migration discourse in particular, it appeared that the EU was demonised instrumentally so that PiS could argue more autonomy for itself. Ahead of the European elections in 2019, when asked what's at stake, Prime Minister Mateusz Morawiecki answered as follows:

There are two things. First, it is about the world of values, second, it is about the material world. In the world of values a dispute has emerged whether to build modernity on the foundation of tradition, family warmth - those good things and good deeds that we have managed to do in the last nearly four years; or whether to build on shocking moral revolutions, where a traditional family is ridiculed and children are subjected to aggressive indoctrination against the will of their parents. We believe that tradition and modernity not only can be reconciled. [...] But modernisation does not have to be at the expense of respect for the past, our history and traditional values. This sets us apart from our political competitors. $^{54}$

This quotation provides an illustration of the constructed antagonism with the EU the "dispute in the world of values". Moreover, the title of the interview republished on PiS website reads "The [European] elections will decide whether we want a strong or submissive Poland". Given the formal nature of the official website and its careful organisation, we

54 Mateusz Morawiecki (Wybory zdecyduja, 2019). 
may assume that this was the main message that the party wanted to communicate. With such discursive means as mentions of disputes, constructed choices between "strong or submissive Poland" and "fighting for Polish matters"55 in the context of the EU, PiS politicians implicitly construct a difference and an antagonism between Poland and the EU. By articulating the perceived need to fight for Polish matters within the EU, they discursively position Poland outside the EU and in opposition to it, rather than as a part of it that it is.

\section{PiS as a messiah}

In both cases PiS positions itself as the protector who will defend Poland against the above-mentioned "threats". It claims it will defend Polish culture, whereas its political opponents will not. Such missionary politics is typical for populists (Zúquete, 2013). Given the contexts of upcoming elections, this is manipulation in order to gain voters' sympathies. The picture below is a particularly vivid example: it depicts PiS as a protective umbrella for 'normal' Polish families (meaning, based on the picture, white, ${ }^{56}$ heterosexual, heteronormative, with children) against the LGBT movement coming at them from above (a threat on the vertical axis). The people in the picture, despite having no other facial features, are smiling. Hence, the two promises PiS implicitly makes here are safety and happiness, or mental security provided by the familiar traditional social reality.

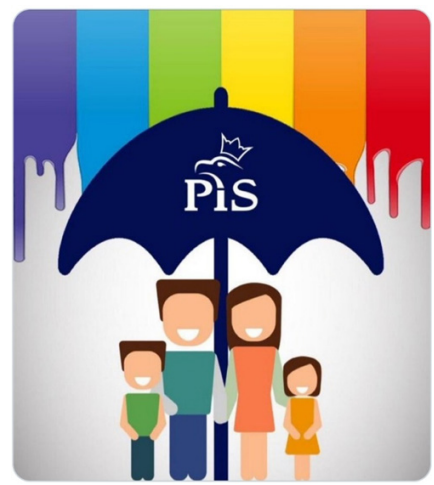

Fig. 1: Picture posted by Stanisław Karczewski on Twitter (@StKarczewski)

\section{Autonomous decision-making powers}

In both cases, one of the argumentation schemes that PiS uses to justify its opposition to an issue at hand is claiming that the matter is simply outside the scope of competencies of "the corrupt elite", not their area of decision-making. In the case of the issue of accepting refugees, "sovereign states must have the ability to decide",57

55 Tomasz Poręba (W Europie głosuj za Polska!, 2019).

56 For an analysis of Polishness as an identity based on racial premises, see Jaskulowski (2020).

57 Mateusz Morawiecki (Wspólnie możemy wpłynąć na losy Europy, 2018). 
(and not the EU). In the case of LGBT discourse and the issue of sex education at schools, "parents have the right to decide" ${ }^{58}$ (and not public officials opposing PiS like Rafat Trzaskowski). In either case, it seems that the sovereign right to decide lies with "the pure people". Who these people are changes instrumentally depending on the context and the situation. In the Polish context, the notion of the Polish family is conflated with the notion of the nation, which in turn is inevitably intertwined with the notion of a nation-state. Ultimately, PiS constructs itself as the representative of the general will of the ('pure') people, as in the end it is them taking decisions in matters of family and matters of state migration policy. The decisions are taken with little to none consideration of other sides of the debate or consultations with (representatives of) the people affected by the issue. Construction of expression of the volonté générale legitimises PiS to take decisions unilaterally, ignoring the other side even when they are screaming at you, quite literally in the case of a pro-LGBT rally in Kraków (Yermakova, 2020). Arguing autonomy is a typical topos in populist discourse.

\section{Conclusions: Populist Fight Against "LGBT Ideology"}

If we deconstruct the right-wing populist triad in Law and Justice's discourse on LGBT, the constructions of social actors are the following:

Table 4: PiS discourse on LGBT in terms of the right-wing populist triad

\begin{tabular}{|c|c|}
\hline Theory (Mudde \& Rovira Kaltwasser, 2017) & LBGT discourse of PiS \\
\hline "the pure people" & 'normal' Catholic heterosexual Polish families \\
\hline "the corrupt elite" & the EU \\
\hline "enemies/aliens" & "LGBT ideology" \\
\hline
\end{tabular}

The discursive discrimination of the LGBT movement serves the political goals of populists in Poland, who try to appeal to emotion, activate fears and prejudices, and claim to defend 'normality'. They single out different minority groups and construct them as enemies, while doing the same with their political opponents, to justify their positions by claiming to defend the general will of the people and gain support based on fear.

In the LGBT case, the enemy is not so much LGBT persons, but what PiS refers to as "LGBT ideology", different value systems, even modernity and progressiveness, and everything that goes against the traditional norms. This neo-traditionalism and rebellion

58 Beata Szydło (W Europie głosuj za Polska!', 2019). 
against modernity is a frequently observed feature of contemporary populists in power. ${ }^{59}$ In many ways, PiS seems to oppose primarily its immediate political opponents in Poland as well as the idea of oversight and influence from the EU, rather than specific issues per se. As we have seen comparing LGBT and migration discourses, the particular issues in question might change (depending on what is salient in public discourse at the moment), but the structure of the discourse, the tropes and topoi used, remain the same.

While in PiS discourse it is the "LGBT ideology", the movement for LGBT rights, that is presented as an enemy, not LGBT Poles themselves, such discursive dehumanisation negatively affects the lives of Polish LGBT persons. Evidence of this is the outrage and protests caused by a statement of Andrzej Duda in June 2020, as well as subsequent demonstrations and actions later that year (Ojewska, 2020). Furthermore, a comprehensive study of the situation of the LGBT movement in Poland points out that "the nationalist politics and rhetoric of the governing PiS has exerted a negative impact on openness towards queer culture and the acceptance of LGBTQ+ rights within Polish society" (Chowaniec et al., 2021, p. 1). Discourse is socially consequential as it (re)produces power relations in a society. First, there have been violent escalations following PiS fuelling antiLGBT discourse. Second, some of the messages promoted (e.g. "rainbow plague") can be classified as homophobic hate speech, contact with which is correlated with mental health issues. Third, in the context of liberal democracy, it is unacceptable for a government to ignore a group of citizens and disqualify it from having civil rights based on differences of identity and deviations from the cultural norm.

Overall, this paper is based on a relatively small research sample. PiS discourse beyond what is available on its website and Twitter needs to be further studied to demonstrate the preliminary conclusions drawn above more definitively. Yet, this paper can serve as an illustration and as a point of departure for deeper investigations into Law and Justice's discourse, ideology, political strategies, and into their vision of the EU and Poland's role in it.

\section{References}

Allen, T. J. (2017). All in the party family? Comparing far right voters in Western and Post-Communist Europe. Party Politics, 23(3), 274-285. https://doi.org/10.1177/1354068815593457

Bielska, B. (2021). 'How does the movement work? Above all, inefficiently': Political outcomes of the Polish LGBT* movement. Central Europe, 19(1), 14-26. https://doi.org/10.1080 /14790963.2021.1920134

59 For more on neo-traditionalism and its relationship with populism in CEE, see POPREBEL project results: https://populism-europe.com/poprebel/ 
Bonikowski, B. (2017). Ethno-nationalist populism and the mobilization of collective resentment. The British Journal of Sociology, 68(S1), 181-213. https://doi.org/10.1111/1468-4446.12325

Brubaker, R. (2017). Between nationalism and civilizationism: The European populist moment in comparative perspective. Ethnic and Racial Studies, 40(8), 1191-1226. https:// doi.org/10.1080/01419870.2017.1294700

Buzalka, J. (2005). Religious populism? Some reflections on politics in post-socialist southeast Poland. Slovak Foreign Policy Affairs, 6(1), 75-84.

CBOS. (2019). Polish public opinion. July/August 2019. https://www.cbos.pl/PL/publikacje /public_opinion/2019/07_08_2019.pdf

Chowaniec, U., Mazierska, E., \& Mole, R. (2021). Queer(in)g Poland in the 21st century: How was it at the beginning of the millennium? Introduction to this special issue on Queer culture and the LGBTQ+ movement in Poland. Central Europe, 19(1), 1-13. https://doi.org /10.1080/14790963.2021.1920131

Cienski, J. (2019, March 10). Poland's ruling party plays the LGBTQ card. Politico. https:// www.politico.eu/article/polands-law-and-justice-plays-the-lgbt-card-ahead-of-elections/

Cohen, S. (2011). Folk devils and moral panics. Routledge. https://doi.org/10.4324 19780203828250

Dehnel, J. (2019, July 28). The struggle for LGBT equality: Pride meets prejudice in Poland. The Guardian. https://www.theguardian.com/world/2019/jul/28/lgbt-gay-rights-poland-first -pride-march-bialystok-rage-violence

Dervin, F. (2015). Discourses of othering. In The international encyclopedia of language and social interaction. John Wiley \& Sons, Inc. https://doi.org/10.1002/9781118611463.wbielsi027

Diez, T. (2005). Constructing the self and changing others: Reconsidering 'normative power Europe'. Millennium: Journal of International Studies, 33(3), 613-636. https://doi.org/10.1177 /03058298050330031701

Erkem, G. P. (2009). Identity construction of Europe by othering: A case study of Turkey and the EU relations from a cultural perspective. Europolis, Journal of Political Science and Theory, 5, 489-509.

European Commission. (2019). Eurobarometer on discrimination 2019: The social acceptance of LGBTI people in the EU

European Parliament. (n.d.). Results by national party: 2014-2019. https://www.europarl .europa.eu/election-results-2019/en/national-results/poland/2014-2019/constitutive -session/

Fairclough, N., \& Wodak, R. (1997). Critical discourse analysis. In T. van Dijk (Ed.), Discourse studies: A multidisciplinary introduction (pp. 258-284). Sage.

Feischmidt, M. (Ed.). (2017). Mobilization through enemy images in Central and Eastern Europe. Intersections: East European Journal of Society and Politics, 3(3), 14-125.

Fergusson, L., Robinson, J. A., Torvik, R., \& Vargas, J. F. (2014). The need for enemies. The Economic Journal, 126(593), 1018-1054. https://doi.org/10.1111/ecoj.12174

Figlerowicz, M. (2019, August 7). The new threat to Poland's sexual minorities: How liberals left LGBTQ people unprotected. Foreign Affairs. https://www.foreignaffairs.com/articles 
/poland/2019-08-07/new-threat-polands-sexual-minorities?utm_medium=promo _email\&utm_source=lo_flows\&utm_campaign=registered_user_welcome\&utm_term=email _1\&utm_content=20210811

Freeden, M. (1996). Ideologies and political theory: A conceptual approach. Oxford University Press. https://doi.org/10.1080/13569310701822289

Gąsior, M. (2014, November 5). CBOS: Polakom nie przeszkadza sąiedztwo geja, prostytutki, przedstawiciela innej rasy. Kobiety bardziej tolerancyjne. NaTemat. https://natemat.pl /122861,cbos-polakom-nie-przeszkadza-sasiedztwo-geja-prostytutki-przedstawiciela -innej-rasy-kobiety-bardziej-tolerancyjne

Gera, V. (2019, April 25). Party leader calls LGBT rights an imported threat to Poland. AP News. https://apnews.com/article/6cb144f6838e409c828cb32a19834a2a

Gerő, M., Płucienniczak, P. P., Kluknavska, A., Navrátil, J., \& Kanellopoulos, K. (2017). Understanding enemy images in Central and Eastern European politics: Towards an interdisciplinary approach. Intersections: East European Journal of Society and Politics, 3(3), 14-40. https://doi.org/10.17356/ieejsp.v3i3.365

Gidron, N., \& Bonikowski, B. (2014). Varieties of populism: Literature review and research agenda (Working Paper Series, 13). SSRN Electronic Journal. https://doi.org/10.2139/ssrn .2459387

Hall, S. (2001). The spectacle of the "other". In S. Hall (Ed.), Representation: Cultural representations and signifying practices (pp. 223-290). Sage Publications.

Hawkins, K. A. (2010). Who mobilizes? Participatory democracy in Chávez's Bolivarian Revolution. Latin American Politics and Society, 52(3), 31-66. https://doi.org/10.1111/j.1548-2456 .2010.00089.x

Heilig, C., \& Lenik, P. (2020). The "good change": Polish populist presidential campaign 2015 and now. The SSEES Research Blog. https://blogs.ucl.ac.uk/ssees/2020/06/23/the-good -change-polish-populist-presidential-campaign-2015-and-now/

Herek, G. M. (1986). On heterosexual masculinity: Some psychical consequences of the social construction. American Behavioural Scientist, 29(5), 563-577. https://doi.org/10.1177 /000276486029005005

Holt, R. R., \& Silverstein, B. (1989). On the psychology of enemy images: Introduction and overview. Journal of Social Issues, 45(2), 1-11. https://doi.org/10.1111/j.1540-4560.1989 .tb01539.x

Hopf, T. (2002). Social construction of foreign policy: Identities and foreign policies, Moscow, 1955 and 1999. Cornell University Press.

ILGA-Europe. (2015). Glossary. https://www.ilga-europe.org/sites/default/files/glossary_october 2015_edition.pdf

Jaskulowski, K. (2020). The politics of a national identity survey: Polishness, Whiteness, and racial exclusion. Nationalities Papers, 2020, 1-14. https://doi.org/10.1017/nps.2020.68 Jung, K., Ang, S. H., Leong, S. M., Tan, S. J., Pornpitakpan, C., \& Kau, A. K. (2002). A typology of animosity and its cross-national validation. Journal of Cross-Cultural Psychology, 33(6), 525-539. https://doi.org/10.1177/0022022102238267 
Kader, N. (2016). A critical analysis of anti-Islamisation and anti-immigration discourse: The case of the English Defence League and Britain First. International Journal for Innovation Education and Research, 4(5), 26-53. https://doi.org/10.31686/ijier.vol4.iss5.538

Kampania Przeciw Homofobii. (2017). Situation of LGBTA persons in Poland: 2015-2016 report. Klaus, W. (2017). Security first: New right-wing government in Poland and its policy towards immigrants and refugees. Surveillance and Society, 15(3-4), 523-528. https://doi.org/10.24908 /ss.v15i3/4.6627

Korolczuk, E. (2019). The fight against 'gender' and 'LGBT ideology': New developments in Poland. European Journal of Politics and Gender, 3(1), 165-167. https://doi.org/10.1332 /251510819X15744244471843

Krzyżanowski, M. (2018). Discursive shifts in ethno-nationalist politics: On politicization and mediatization of the "refugee crisis" in Poland. Journal of Immigrant and Refugee Studies, 16(1-2), 76-96. https://doi.org/10.1080/15562948.2017.1317897

Kubik, J. (2018). The POPREBEL and FATIGUE Manifesto. https://populism-europe.com/wp -content/uploads/2020/09/Working-Paper-1.pdf

Łaciak, B., \& Segeš Frelak, J. (2018). The wages of fear: Attitudes towards refugees and migrants in Poland. Instytut Spraw Publicznych.

Mach, Z. (2007). The Roman Catholic Church in Poland and the dynamics of social identity in Polish society. In L. Faltin \& M. J. Wright (Eds.), The religious roots of contemporary European identity (pp. 117-133). Continuum.

Mizielińska, J., \& Stasińska, A. (2013). Od "wroga rodziny" do jednej z jej form: Rodziny z wyboru we współczesnym polskim dyskursie prasowym. InterAlia: Pismo Poświęcone Studiom Queer, 8, 105-128. https://doi.org/10.51897/interalia/GSPB6363

Moffitt, B. (2016). The global rise of populism: Performance, political style, and representation. Stanford University Press.

Mole, R. (2011). Nationality and sexuality: Homophobic discourse and the 'national threat' in contemporary Latvia. Nations and Nationalism, 17(3), 540-560. https://doi.org/10.1111/j .1469-8129.2010.00476.x

Mole, R., Golec de Zavala, A., \& Ardag, M. M. (2021). Homophobia and national collective narcissism in populist Poland. European Journal of Sociology, 2021, 1-34.

Mudde, C. (2004). The populist Zeitgeist. Government and Opposition, 39(4), 541-563. https://doi.org/10.1111/j.1477-7053.2004.00135.x

Mudde, C. (2007). Populist radical rigt parties in Europe. Cambridge University Press.

Mudde, C., \& Rovira Kaltwasser, C. (2017). Populism: A very short introduction. Oxford University Press. https://doi.org/10.1093/actrade/9780190234874.001.0001

Müller, J.-W. (2016). What is populism? University of Pennsylvania Press. https://doi.org /10.9783/9780812293784

Neumann, I. (1999). Uses of the other: "The East" in European identity formation. University of Minnesota Press. 
Nowa Piątka PiS to inwestycja w przyszłość. (2019, March 8). Prawo i Sprawiedliwość - Internetowy Serwis Informacyjny. http://pis.org.pl/aktualnosci/nowa-piatka-pis-to-inwestycjaw-przyszlose

Ojewska, N. (2020, October 6). Poland's culture war: LGBT people cornered by toxic politics are turning to civil disobedience. Euronews. https://www.euronews.com/2020/10/06 /poland-s-culture-war-lgbt-people-cornered-by-toxic-politics-are-turning-to-civil-disobedie Panizza, F. (Ed.). (2005). Populism and the mirror of democracy. Verso.

Pankowski, R. (2010). The populist radical right in Poland: The patriots. Routledge. https:// doi.org/10.4324/9780203856567

Polska Plus czy Polska Minus - O tym będziemy decydować 13 października. (2019, October 9). Prawo i Sprawiedliwość - Internetowy Serwis Informacyjny. http://pis.org.pl/aktualnosci/polska -czy-polska-minus-o-tym-bedziemy-decydowac-13-pazdziernika

Porter, B. (2001). The Catholic nation: Religion, identity, and the narratives of Polish history. The Slavic and East European Journal, 45(2), 289-299. https://doi.org/10.2307/3086330

Ramet, S. P. (1999). Defining the radical right: Values and behaviors of organized intolerance in post-communist Central and Eastern Europe. In S. P. Ramet (Ed.), Radical right in Central and Eastern Europe since 1989 (pp. 3-27). Pennsylvania State University Press.

Regmi, K. D. (2017). Critical discourse analysis: Exploring its philosophical underpinnings. Méthod(e)s: African Review of Social Sciences Methodology, 2(1-2), 93-107. https://doi.org /10.1080/23754745.2017.1354555

Reisigl, M., \& Wodak, R. (2001). Discourse and discrimination: Rhetorics of racism and antisemitism. Routledge. https://doi.org/10.4324/9780203993712

Rooduijn, M., \& Pauwels, T. (2011). Measuring populism: Comparing two methods of content analysis. West European Politics, 34(6), 1272-1283. https://doi.org/10.1080/01402382 .2011 .616665

Rooduijn, M., Van Kessel, S., Froio, C., Pirro, A., De Lange, S., Halikiopoulou, D., Lewis, P., Mudde, C., \& Taggart, P. (2019). The PopuList: An overview of populist, far right, far left and Eurosceptic parties in Europe. http://www.popu-list.org

Rovira Kaltwasser, C. (2012). The ambivalence of populism: Threat and corrective for democracy. Democratization, 19(2), 184-208. https://doi.org/10.1080/13510347.2011.572619

Schmitt, C. (2007). Theory of the partisan: Intermediate commentary on the concept of the political. Telos Press Publishing.

Shotter, J. (2019, August 11). Poland's ruling party fuels anti-LGBT sentiment ahead of elections. Financial Times. https://www.ft.com/content/e815df96-bb8f-11e9-89e2-41e555e96722

Tilles, D. (2020, May 20). Elections are "a choice between white-and-red Poland and rainbow Poland", says ruling party official. Notes from Poland. https://notesfrompoland.com /2020/05/20/elections-are-a-choice-between-white-and-red-poland-and-rainbow -poland-says-ruling-party-official/

Tok FM. (2020, June 13). Andrzej Duda znów o LGBT. "Próbuje się nam wmówić, że to ludzie, a to jest po prostu ideologia". Tok FM. https://www.tokfm.pl/Tokfm/7,103087,26028952,andrzej-duda -znow-o-lgbt-probuje-sie-nam-wmowic-ze-to-ludzie.html 
UCSF LGBT Resource Center. (n.d.). General definitions. https://lgbt.ucsf.edu/glossary-terms W Europie głosuj za Polska! Wybierz listę nr 4 Prawo i Sprawiedliwość! (2019, May 20). Prawo i Sprawiedliwość - Internetowy Serwis Informacyjny. http://pis.org.pl/aktualnosci/w-europie -glosuj-za-polska-wybierz-liste-nr-4-prawo-i-sprawiedliwosc

Wodak, R., \& Meyer, M. (2008). Critical discourse analysis: History, agenda, theory, and methodology. In R. Wodak \& M. Meyer (Eds.), Methods for critical discourse analysis (pp. 1-33). SAGE.

Wodak, R., \& Reisigl, M. (2015). Discourse and racism. In D. Tannen, H. E. Hamilton, \& D. Schiffrin (Eds.), The handbook of discourse analysis (2nd ed., pp. 576-596). Wiley Blackwell. https://doi.org/10.1002/9780470753460.ch20

Wspólnie możemy wpłynąć na losy Europy. (2018, January 3). Prawo i Sprawiedliwość Internetowy Serwis Informacyjny. http://pis.org.pl/aktualnosci/wspolnie-mozemy-wplynac -na-losy-europy

Wybory zdecyduja, czy chcemy Polski silnej, czy uległej. (2019, May 24). Prawo i Sprawiedliwość - Internetowy Serwis Informacyjny. http://pis.org.pl/aktualnosci/wybory-zdecyduja -czy-chcemy-polski-silnej-czy-uleglej

Wysocka, O. (2008). Populizm i Radio Maryja. Znak, 2008(640), 61-74.

Yermakova, O. (2019). Mythology of the Law and Justice Party's migration discourse. Politeja, 16(6(63)), 177-195. https://doi.org/10.12797/Politeja.16.2019.63.12

Yermakova, O. (2020, July 14). LGBT resistance to Polish populism, or "what true Poland looks like": Notes from an LGBT protest in Krakow. Fatigue Blog. https://populism-europe.com /lgbt-resistance-to-polish-populism-or-what-true-poland-looks-like-notes-from-an-lgbt -protest-in-krakow/

Zúquete, J. P. (2013). Missionary politics: A contribution to the study of populism. Religion Compass, 7(7), 263-271. https://doi.org/10.1111/rec3.12048

\title{
PiS vs LGBT. Kształtowanie obrazu "Innego" w przypadku ruchu LGBT jako element dyskursu populistycznej radykalnej partii prawicowej w Polsce
}

\begin{abstract}
Abstrakt
Artykuł analizuje, w jaki sposób ruch LGBT jest przedstawiany jako „Inny" w celu dopasowania go do prawicowego populistycznego dyskursu, a tym samym jak jest wykorzystywany jako element strategii politycznej przez prawicowych populistycznych aktorów. Koncentruję się na Prawie i Sprawiedliwości, polskiej populistycznej partii radykalnej prawicy (u władzy nieprzerwanie od 2015 roku), której retoryka anty-LGBT nasiliła się na nowo przed wyborami do Parlamentu Europejskiego w 2019 roku. Przeprowadzając krytyczną analizę dyskursu (w oparciu o ramy analityczne Ruth Wodak i Martina Reisigla) wybranych tekstów i materiałów wizualnych z oficjalnej strony internetowej partii oraz kont jej czołowych członków na Twitterze, przeanalizowałam, jakimi środkami dyskursywnymi
\end{abstract}


przedstawiciele partii kształtują obraz Polaków LGBT jako „Innych”, jak umieszczają homofobię w ramach szerszego populistycznego dyskursu i jak instrumentalizują ją dla uzyskania politycznych korzyści. Porównuję wyniki moich badań z wynikami analizy antymigracyjnego dyskursu Prawa i Sprawiedliwości przed wyborami parlamentarnymi w 2015 roku. Prace są prowadzone w ramach szerszego projektu na temat „inności” w ramach współczesnego prawicowego populizmu w Europie Środkowo-Wschodniej.

Słowa kluczowe: LGBT; homofobia; prawica; populizm; Polska; Prawo i Sprawiedliwość; dyskurs

\section{Citation}

Yermakova, O. (2021). PiS vs LGBT: The "othering" of the LGBT movement as an element of populist radical right party discourse in Poland. Sprawy Narodowościowe: Seria nowa, 2021(53), Article 2568. https://doi.org/10.11649/sn.2568 